\title{
Vertical dynamics and reproductive behaviour of farmed and wild Atlantic cod Gadus morhua
}

\author{
Justin J. Meager ${ }^{1, *}$, Jon Egil Skjæraasen ${ }^{1}$, Anders Fernö ${ }^{1,2}$, Ørjan Karlsen ${ }^{3}$, \\ Svein Løkkeborg ${ }^{2}$, Kathrine Michalsen ${ }^{2}$, Stig Ove Utskot ${ }^{3}$ \\ ${ }^{1}$ Department of Biology, University of Bergen, 5020 Bergen, Norway \\ ${ }^{2}$ Institute of Marine Research, 5817 Bergen, Norway \\ ${ }^{3}$ Institute of Marine Research, Austevoll Research Station, 5932 Storebø, Norway
}

\begin{abstract}
Rapid development of fish mariculture and efforts to restock depleted populations have raised concerns about the effects on wild populations and the risk of genetic introgression from hybridisation. Reproduction of many marine fish species involves substantial vertical movements, but nothing is known of the vertical dynamics of farmed fish in spawning shoals. We combined laboratory observations and field biotelemetry to examine the depth-related reproductive behaviour and vertical dynamics of individual farmed and wild Atlantic cod Gadus morhua (L). We first tested the prediction that the depth distributions of male and female wild cod differ both in the laboratory and in the field. We then tested the prediction that farmed cod have a shallower depth distribution than wild cod and thus lack the sex-based vertical dynamics of wild cod. In both the laboratory and field, male farmed and wild fish tended to be located deeper than females, and wild fish were deeper than farmed fish. In the field, wild males were near the seafloor, considerably deeper than wild females and farmed fish. Residency on the spawning ground was longer for wild fish, but a substantial proportion $(61 \%)$ of farmed fish remained for more than $3 \mathrm{~d}$. Our study reinforces the idea that vertical dynamics play a key role in reproduction of an important fisheries species, and demonstrates clear differences in vertical distribution between farmed and wild fish on a spawning ground. The results suggest that escaped farmed cod, and in particular, farmed females, are likely to hybridise with wild cod.
\end{abstract}

KEY WORDS: Aquaculture $\cdot$ Escaped $\cdot$ Gadus morhua $\cdot$ Depth $\cdot$ Mating behaviour $\cdot$ Spawning

\section{INTRODUCTION}

In aquatic and marine environments, vertical dynamics have a key role in fitness-related behaviours such as foraging, predator avoidance and reproduction (Clark \& Levy 1988, Neilson \& Perry 1990). However, when species such as teleost fishes are domesticated or captive-reared for aquaculture or re-introduction programmes, they are usually kept in shallow tanks or sea pens. These conditions, in concert with high stocking densities, a general absence of predators, surface feeding and artificial selection regimes, are likely to result in rapid divergence in depth-related behaviour between farmed and wild fish (Reinhardt 2001). Indeed, farmed fish often maintain positions closer to the surface than their wild counterparts (Vincent 1960, Dickson \& MacCrimmon 1982), often for substantial periods of time after release (Svåsand \& Kristiansen 1990). This is thought to contribute to poor survival of farmed fish in restocking and stock enhancement programs, by reducing encounters with benthic food items and by increasing their vulnerability to predation (Olla et al. 1994). However, the establishment of farmed fish populations in the wild also depends on their ability to reproduce, and very little is known of the depth-related behaviour of farmed fish in relation to spawning.

The vertical distribution of farmed fish in the wild is likely to affect the extent to which they compete with wild fish for mates and interbreed with wild popula- 
tions. Depth-related movements also have a fundamental role in the spawning behaviour of many teleosts (e.g. Baird \& Olla 1991, Lobel 1992, Pankhurst \& Fitzgibbon 2006). Spawning ascents, for example, are thought to be related to increased survival or dispersal of eggs in surface waters (Kjesbu et al. 1992, Bradbury et al. 2000), and vertical positioning can be closely linked to courtship behaviour (e.g. Brawn 1961, Hutchings et al. 1999).

The depth-related behaviour of farmed fish in the wild is likely to be important not only in regards to intentional releases, but also in assessing the impact of escapes from aquaculture on wild stocks. This is particularly relevant for species that have considerable vertical movements related to reproduction or that spawn at substantial depths, which includes many marine fishes now considered for mariculture, such as Atlantic cod Gadus morhua (L.) (Hutchings et al. 1999) flatfishes (Pankhurst \& Fitzgibbon 2006) and bluefin tuna (Thunnus spp.; Rooker et al. 2007).

Cod are an ideal model species to test for the effects of farming on the vertical dynamics of spawning behaviour, because their mating system is comparatively well understood. There has also been increasing concern about impacts of escapes from the burgeoning cod aquaculture industry on wild cod populations (Naylor et al. 2005, Bekkevold et al. 2006, Moe et al. 2007). Coastal cod populations have a localised genetic structure that may make them particularly vulnerable to hybridisation with farmed fish (Bekkevold et al. 2006). To date, escape rates have been surprisingly high, and in Norway, where most cod are produced, over 800000 cod were reported to have escaped between 2004 and 2008 (Norwegian Directorate of Fisheries, official statistics). Cod farms are often located close to coastal cod spawning grounds in sheltered coastal areas. Numerous studies have indicated that farmed cod are able to navigate to such local spawning grounds, because fish released as either juveniles or adults have been re-caught at known spawning sites (Svåsand et al. 1990, Wroblewski et al. 1996, Nøstvik \& Pedersen 1999, Uglem et al. 2008).

The mating behaviour of cod is complex and resembles a lek (Nordeide \& Folstad 2000, Windle \& Rose 2006). Males compete aggressively for courtship with females using behavioural displays and acoustic vocalisations (Brawn 1961, Hutchings et al. 1999, Rowe et al. 2008). Spiralling ascents by the mated pair have also been observed prior to successfully spawning in the laboratory (Brawn 1961, Hutchings et al. 1999). It is thought that these behaviours are an underlying cause of the vertical dynamics often observed in wild spawning shoals (Brawn 1961, Lawson \& Rose 2000, Rose 1993). Males and females are also spatially separated on spawning grounds, with females thought to attend male-dominated aggregations only when they are ready to spawn (Windle \& Rose 2006). This is thought to be the main reason for depth-related patterns in sexskewed fishing catches of cod on numerous spawning grounds (Morgan \& Trippel 1996, Nordeide \& Folstad 2000, Windle \& Rose 2006). Hence, the vertical behaviour of cod on spawning grounds is not only likely to differ between farmed and wild fish, but this difference is likely to depend on fish sex.

The vertical dynamics of fish are further complicated by factors such as physiological limitations imposed by swimbladder function (Harden Jones \& Scholes 1985, Bone et al. 2004), as well as water currents, light and temperature (Aglen et al. 1999). Separating the behavioural and environmental effects requires observations of behaviour over a limited depth range under controlled laboratory conditions. Laboratory studies also allow for detailed investigation of individual behaviour that has to date proved impossible in the wild.

In our study, we used a combined laboratory and field approach to compare the sex-based vertical dynamics and reproductive behaviour of farmed and wild cod. We examined behaviour in detail in the laboratory (Expt 1), and then scaled the experiment up to track the vertical movements of farmed and wild cod on a natural spawning ground (Expt 2). As this is the first fine-spatial scale study of the sex-based vertical dynamics of cod at the individual level, we first tested the prediction that the depth distributions of male and female wild cod differ both in the laboratory and field. We then tested the prediction that farmed cod have a shallower depth distribution than wild cod in both experiments, and thus do not have the same clear vertical separation between sexes as wild fish.

\section{MATERIALS AND METHODS}

In Expt 1, we observed and quantified the reproductive behaviour and vertical distribution of farmed and wild cod in an indoor tank. We then used ultrasonic telemetry in Expt 2 to examine the vertical dynamics of individual farmed and wild cod on a natural spawning ground. The fish in both experiments were either wildcaught or farmed first-generation offspring of coastal cod from the Bergen region of western Norway.

Expt 1: Laboratory study. Experimental fish: Wild coastal cod were caught by hook and line, and fish traps at 6 to $20 \mathrm{~m}$ depth in the Herdla-Øygarden area of western Norway: 51 fish were caught at $60^{\circ} 29^{\prime} \mathrm{N}$ and $4^{\circ} 53^{\prime} \mathrm{E}$, and 24 fish were caught at $60^{\circ} 34^{\prime} \mathrm{N}$ and $4^{\circ} 56^{\prime} \mathrm{E}$. The former were caught between November and December 2005 and kept in a large $800 \mathrm{~m}^{3}$ sea pen (13 $\mathrm{m} \varnothing, 6 \mathrm{~m}$ depth) for 1 to $2 \mathrm{mo}$ after capture, and the latter were caught in early January 2006 and 
kept in submerged cages $(1 \mathrm{~m}$ length, $60 \mathrm{~cm}$ width, $1 \mathrm{~m}$ depth) for $2 \mathrm{wk}$. Wild fish were transported to an indoor seawater tank (5 $\mathrm{m} \varnothing, 1.4 \mathrm{~m}$ depth, $27.5 \mathrm{~m}^{3}$ ) at the Institute of Marine Research (IMR) facility at Austevoll $\left(60^{\circ} 5^{\prime} \mathrm{N}, 5^{\circ} 15^{\prime} \mathrm{E}\right)$ in January. These fish were age 3 to $5 \mathrm{yr}$ and were a mixture of fish that had spawned previously (repeat spawners) and firsttime spawners (recruit spawners), based on otolith analyses and the presence of a spawning check (Rollefsen 1933). Farmed fish were the F1 offspring of wild broodstock caught at Øygarden $\left(60^{\circ} 29^{\prime} \mathrm{N}\right.$, $\left.4^{\circ} 53^{\prime} \mathrm{E}\right)$, spawned spring 2004 and 2003 and raised under commercial conditions at IMR. Farmed fish were age 2 to 3 and were a mixture of recruit and repeat spawners.

At IMR, the fish were kept under a natural photoperiod, supplied with flow-through seawater and fed a mixture of herring and pellets. Egg collectors that skimmed the surface of each tank were monitored daily for the presence of eggs. On 20 February, shortly after eggs were discovered for the first time, we sedated the fish ( $0.5 \mathrm{~g} \mathrm{l}^{-1}$ Metacaine) and assessed sex and maturation stage, either by the presence of sperm or by ultrasonography (Karlsen \& Holm 1994). Fish that had either commenced spawning or were considered to be close to spawning based on the ultrasonic image were selected for the experiment. Total length and whole body weight were then recorded, and fish were individually tagged with 2 white $7 \mathrm{~cm}$ Floy T-bar tags (following Hutchings et al. 1999).

Experimental tank and experimental protocol: The experimental tank ( $7 \mathrm{~m} \varnothing, 1.4 \mathrm{~m}$ depth) was indoors, supplied with flow-through seawater at $120 \pm 6.81$ $\min ^{-1}$ (mean $\pm \mathrm{SD}$ ) and had a relative pressure range of 0.14 absolute atmospheres (ATA). Temperature, salinity and oxygen were monitored daily. Light levels $\left(0.22 \mu \mathrm{mol} \mathrm{m}^{-2} \mathrm{~s}^{-1}\right)$ were equivalent to within natural spawning shoals (J. Meager unpublished data) and were controlled by dimming switches set to the local photoperiod.

Fish were released into the tank on 23 February. The number of fish of each sex and fish origin were matched at a density of 0.74 fish $\mathrm{m}^{-3}$ (40 fish), representing a dense natural spawning shoal, but below the maximum reported in the field (Rose 1993). Fish sizes were matched as closely as possible (Table 1), but variance in growth rate and condition between farmed and wild cod (e.g. Kjesbu 1989) meant that absolute size matching was not possible without introducing substantial biases, i.e. by starving farmed fish. Wild cod were longer on average than farmed cod (females: Student's $t=-4.24$, df $=18$, p $<0.001$; males: $t=-2.65, \mathrm{df}=18, \mathrm{p}=0.016)$, but weights were similar within males and females $(p=0.13$ and 0.67 ; Table 1).
Table 1. Gadus morhua. Details of fish used in the laboratory experiment. Farmed fish were age 2 to 3 and wild fish were age 3 to $5 \mathrm{yr}$, and both types were mixes of recruit and repeat spawners. Condition was calculated as Fulton's $K(100 \times$ weight/length ${ }^{3}$ ). Data are mean $\pm \mathrm{SD}$

\begin{tabular}{|lcccc|}
\hline $\begin{array}{l}\text { Type and } \\
\text { sex }\end{array}$ & $\mathrm{n}$ & $\begin{array}{c}\text { Standard } \\
\text { length }(\mathrm{cm})\end{array}$ & $\begin{array}{c}\text { Weight } \\
(\mathrm{kg})\end{array}$ & $\begin{array}{c}\text { Condition } \\
(K)\end{array}$ \\
\hline Farmed $\circ$ & 10 & $55.2 \pm 2.44$ & $2.68 \pm 0.51$ & $1.56 \pm 0.14$ \\
Farmed o & 10 & $54.5 \pm 1.38$ & $2.03 \pm 0.15$ & $1.29 \pm 0.11$ \\
Wild $\%$ & 10 & $60.7 \pm 3.30$ & $2.33 \pm 0.46$ & $1.03 \pm 0.16$ \\
Wild $0^{7}$ & 10 & $57.5 \pm 3.81$ & $1.99 \pm 0.30$ & $1.04 \pm 0.09$ \\
\hline
\end{tabular}

Behavioural observations: The tank was filmed with 1 CCTV camera (Panasonic WV BP550) located $3 \mathrm{~m}$ above the water surface, and 2 underwater CCTV cameras (8100-FR129 Futura Elettronica, 1/3' SONY CCD) placed on opposing sides of the tank at $0.7 \mathrm{~m}$ depth. Cameras were synchronised with a multiplexor (Panasonic WJ-MS4244), and the tank was filmed daily for $8 \mathrm{~h}$ between 10:30 and 18:30 h. We analysed the vertical distribution and behaviour of individual fish for a minimum of $2 \mathrm{~h}$ each day for $20 \mathrm{~d}$ (75.2 $\mathrm{h}$ in total), from 7 to 26 March. We recorded the depth stratum (surface, midwater or bottom) of every reproductive behaviour observed, and the depth stratum and behaviour of every individual identified. Behavioural acts associated with reproduction were scored as: 'Chase', 'Flee', 'Approach', 'Circling', 'Lateral display', 'Paired swim', 'Dorsal mount', 'Ventral mount' and 'Spawning' (see Appendix 1 for further descriptions of reproductive behaviours). Depth strata corresponded to 3 equal sections that were marked on the screen of the viewing monitor and aligned with known landmarks on the opposing tank wall.

Statistical procedures: We tested whether (1) the depth distribution of individuals varied with fish type and sex, and (2) fish reproductive behaviour varied with depth. For the first test, we used a generalised linear mixed-effect model with a logit link function (lme4 package of $\mathrm{R}$ version 2.6, R Development Core Team 2008). Fish depth (i.e. bottom versus surface) was the binomial response variable, fish sex and type were the fixed effects, and we used a random effect for individual fish. Only bottom and surface depth strata were included in this analysis, because fish in the middle depth category were closer to the camera and hence more likely to be identified. Log-likelihood ratios $\left(G^{2}\right)$ were used to arrive at the final model that was fitted with restricted maximum likelihood (REML). For the second test, we compared reproductive behaviour between the 3 depth strata using multivariate analysis of variance (Type IV MANOVA, SPSS 14). The dependent variables were the daily mean of observations in the 5 most frequent behavioural acts: approach, chase, 
dorsal mount, paired swim and ventral mount. Data were log-transformed because of heterogeneous variances, and where significant, univariate analysis of variance (ANOVA) was used to test for differences in behavioural rates.

Expt 2: Field study. Study site and experimental fish: The study was conducted on a known coastal cod spawning ground, at Austevoll, western Norway (Fig. 1). The main spawning aggregation here (termed 'spawning arena', Fig. 1) is associated with a rocky slope from 30 to $68 \mathrm{~m}$ depth (J. Meager unpublished data) at the mouth of the bay, and represents a typical spawning site for coastal cod (sensu Ames 2004). Depths over the entire spawning ground range from 5 to $92 \mathrm{~m}$. Wild coastal cod were caught at this site using fish traps and nets set at 5 to $25 \mathrm{~m}$ depth, from midDecember 2006 to early February 2007. Captured fish were brought slowly to the surface to prevent barotrauma and were kept in 2 sea pens ( $1 \mathrm{~m} \varnothing, 4 \mathrm{~m}$ depth), at a location $2.8 \mathrm{~km}$ away from the study site.

Farmed fish were obtained at harvest size from a commercial cod farm at Fitjar $\left(59^{\circ} 58^{\prime} \mathrm{N}, 5^{\circ} 21^{\prime} \mathrm{E}\right)$. These fish were age 3 and had previously spawned at age 2. The parental fish were wild-caught nearby at Bømlo (59 53' N, $\left.5^{\circ} 5^{\prime} \mathrm{E}\right)$, and the fish were on-grown in sea pens $(15 \times 15 \mathrm{~m}, 12 \mathrm{~m}$ deep net pen) at densities from 3 to 6 fish $\mathrm{m}^{-3}$ and surface fed with commercial pellets. In January 2007, the fish were transferred to 2 sea pens ( $1 \mathrm{~m} \varnothing, 4 \mathrm{~m}$ depth) adjacent to the wild cod.

In mid-February 2007, fish were anaesthetised with $0.5 \mathrm{~g} \mathrm{l}^{-1}$ Benzocaine. As in Expt 1, sex and reproductive status were then determined, total length and body weight were recorded, and fish were individually tagged with external Floy T-bar tags. Acoustic tags (full description below) were intraperitoneally implanted into 48 fish (12 from each sex and type) that matched the following criteria: (1) $1 \mathrm{wk}$ or less from

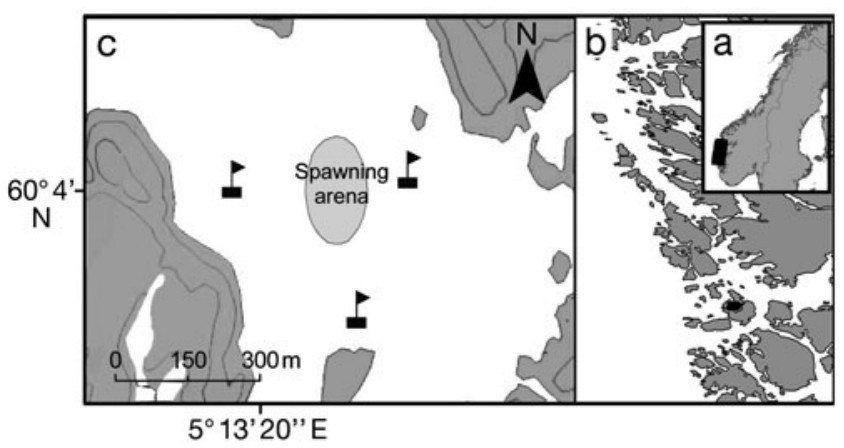

Fig. 1. Location of study area in (a) Norway and (b) western Norway. The maximum depth in the study area (c) was $92 \mathrm{~m}$. The locations of the hydrophone receivers are indicated by the buoy symbols. The 'spawning arena' (sensu Hutchings et al. 1999) was the area where most of the core-utilisation areas for wild males overlapped (50\% kernel densities, J. Meager unpubl. data) spawning based on the ultrasound image, (2) absence of morphological abnormalities or parasites that may affect behaviour.

Fish were size matched as closely as possible (Table 2). Farmed female cod were of similar length and weight to wild female cod (separate-variance $t$-test of length: $t=-1.27, \mathrm{df}=11.7, \mathrm{p}=0.22$; Student's $t$-test of weight: $t=-0.64, \mathrm{df}=22, \mathrm{p}=0.54$ ). Wild males were slightly longer than farmed males (separate-variance $t$-test: $t=-2.35, \mathrm{df}=13.2, \mathrm{p}=0.035$ ), but weights were very similar (separate-variance $t$-test: $t=-0.39, \mathrm{df}=$ 14.6, $\mathrm{p}=0.7$ ).

Fish were allowed to recover in aerated tanks for approximately $1 \mathrm{~h}$ and monitored for signs of stress, such as abnormal swimming. They were then transferred back to the sea pens for 4 to $5 \mathrm{~d}$ of further recovery before release at the spawning ground on 19 February. The main spawning period at this location is from mid-February to mid-March (information from local fishermen). Shortly after release, spawning by cod was confirmed by the presence of recently fertilised eggs and by hydrophone recordings of male mating calls (J. Skjæraasen \& J. Meager unpubl. data).

Biotelemetry: We used a stationary positioning system (VRAP, Vemco) to track cod tagged with ultrasonic transmitters for 35 d (19 February to $25 \mathrm{March}$ ). The positioning system had a fixed array of 3 hydrophone receivers and was anchored to the sea floor in a triangular configuration with distances between the buoys ranging from 310 to $375 \mathrm{~m}$ (Fig. 1). The receivers on the buoys collected transmitter data, which were then dispatched by radio to a base station where a computer program (VRAP 5.1.4, Vemco) used the arrival times of the acoustic pulses to track the position of each fish in real time.

Table 2. Gadus morhua. Details of fish tagged with acoustic transmitters. Two separate transmitter systems were used: continuous tags (Cont.) tracked at a high-temporal resolution on separate frequencies, and individually coded tags (Coded) that allowed a large number of fish to be tracked on a single frequency. Data are mean $\pm \mathrm{SD}$

\begin{tabular}{|lcccc|}
\hline $\begin{array}{l}\text { Tag \& Fish type } \\
\text { and sex }\end{array}$ & $\mathrm{n}$ & $\begin{array}{c}\text { Standard } \\
\text { length }(\mathrm{cm})\end{array}$ & $\begin{array}{c}\text { Weight } \\
(\mathrm{kg})\end{array}$ & $\begin{array}{c}\text { Condition } \\
(K)\end{array}$ \\
\hline Coded & & & & \\
$\quad$ Farmed o & 10 & $61.8 \pm 1.6$ & $3.42 \pm 0.49$ & $1.45 \pm 0.20$ \\
Farmed ơ & 10 & $61.2 \pm 1.9$ & $2.90 \pm 0.39$ & $1.26 \pm 0.07$ \\
Wild o & 10 & $65.2 \pm 9.6$ & $3.18 \pm 1.80$ & $1.07 \pm 0.04$ \\
Wild ơ & 10 & $66.0 \pm 6.6$ & $3.09 \pm 1.02$ & $1.05 \pm 0.06$ \\
Cont. & & & & \\
Farmed o & 2 & $62.5 \pm 2.1$ & $3.53 \pm 0.57$ & $1.44 \pm 0.09$ \\
Farmed ơ & 2 & $63.5 \pm 0.8$ & $3.26 \pm 0.18$ & $1.27 \pm 0.08$ \\
Wild o & 2 & $65.0 \pm 1.4$ & $2.85 \pm 0.06$ & $1.04 \pm 0.06$ \\
Wild ơ & 2 & $65.5 \pm 3.5$ & $3.02 \pm 0.48$ & $1.07 \pm 0.002$ \\
& & & & \\
\end{tabular}


We used 2 separate transmitter systems (Table 2): continuous tags (Vemco V16P-4H) that enabled tracking at a high temporal resolution on a limited number of separate frequencies, and individually coded tags (Vemco V16P-4H S256) that allowed a large number of fish to be tracked on the same frequency. Our 8 continuous tags ( 2 fish from each sex and type) operated on separate frequencies from 51 to $81 \mathrm{kHz}$, and our 40 coded tags (10 fish from each sex and type) operated on a frequency of $69 \mathrm{kHz}$. All tags were equipped with a depth sensor and weighed $12 \mathrm{~g}$ in water $(\varnothing: 16 \mathrm{~mm}$, length: $71 \mathrm{~mm}$ ).

Depth data were received for all fish throughout the study, but the VRAP system was only able to track the $3 \mathrm{D}$ positions of fish at 1 frequency at a time. We therefore cycled between tracking coded tags for $72 \mathrm{~h}$ and continuous tags for $24 \mathrm{~h}$. Coded tags were set to use a random delay of between 150 and 250 s between transmissions, to minimise collisions between tag signals. This led to an average sampling interval of $13.3 \mathrm{~min}$ (range: 3.8 to $44.2 \mathrm{~min}$ ), assuming that all tags were within range at the same time. When tracking fish with continuous tags, the system was set to cycle between frequencies and track each continuous tag at intervals of $144 \mathrm{~s}$. Daily residency was defined as at least 1 buoy receiving at least 1 signal for a given fish, which meant that the fish was close to the spawning ground, because the maximum range of each transmitter was $1 \mathrm{~km}$.

Data analysis: Depth data were filtered to remove erroneous values that occurred when the system did not receive depth data for a given fish position. Distances from the seafloor were calculated only when the 3D position of a fish was resolved. Each position was the average of the $80 \%$ best aligned pulses (position average algorithm in the VRAP program). Positions were then further filtered for errors in positional calculation, which can result from environmental noise, echoes and distance from the positioning system. We excluded positions where (1) distance from the nearest receiver buoy exceeded $1 \mathrm{~km}$, and (2) $\sqrt{ } D / P \geq 5$, where $D$ is the standard deviation between pulses in a set of aligned data and $P$ is the number of pulses received that could be assumed to originate from the same transmitter (Zamora \& Moreno-Amich 2002). The filtered positions were then converted to geodetic coordinates using reference points recorded with a global positioning system (GPS; Garmin), and transferred to a geographical information system (GIS) using ArcGIS (ESRI, Version 9.2). Distances from the seafloor were obtained by matching the positions of fish to a bathymetric map based on echosounding depths (SIMRAD EY500, $70 \mathrm{kHz}$ transducer) that was interpolated by kriging.
We tested for differences in mean residency between fish type and sex using a fixed-effect ANOVA on data that were log-transformed because of non-normality. Examination of time-depth scatter plots revealed that most fish normalised their vertical distribution within the first $24 \mathrm{~h}$, hence data for the first $24 \mathrm{~h}$ were excluded from the following analyses. Mean depth was compared between fish sex, type and diel period (day: sunrise to sunset; night: sunset to sunrise) using linearmixed modelling (nlme package, $\mathrm{R}$ version 2.6 ). The fixed effects were fish sex, fish type and diel period, and the random effect was nested to control for diel and daily variation in the depths of individual fish. We used log-likelihood ratios $\left(G^{2}\right)$ to arrive at the final model that was fitted with REML. The same fixed and random effects were used in the analysis for the distance from seafloor data.

Although the focus of our paper was on vertical dynamics, we also used a dispersion metric to give a general spatial description of fish positions over the spawning ground in relation to the main spawning aggregation near the centre of the buoy array (Fig. 1). Positions were converted to distances from the centre of the array, and the upper $90 \%$ quantile of these distances was calculated for each fish. For each group of fish type and sex, dispersion was calculated as the radius of a circle from the centre of the buoy array that contained $90 \%$ of the $90 \%$ quantiles (i.e. $90 \%$ of the positions of $90 \%$ of the individuals).

\section{RESULTS}

\section{Expt 1. Laboratory study: depth distribution and reproductive behaviour}

Fish depth was influenced by fish type (depth $\times$ type interaction: $G^{2}=43.7, \mathrm{p}<0.001,584$ observations) and fish sex (sex $\times$ depth interaction: $G^{2}=30.1$, p < 0.001), but not by an interaction of sex and type (sex $\times$ type $\times$ depth: $G^{2}=0.15, p=0.92$ ). Wild fish were closer to the bottom of the tank than farmed fish $(B=1.64, \mathrm{p}=$ 0.001 ), and males were significantly closer to the bottom than females ( $B=1.37, \mathrm{p}=0.005$; Fig. 2 ).

The 'paired swim' behaviour was by far the most frequent reproductive behaviour observed and accounted for $56 \%$ of observed reproductive behaviours $(n=593)$, while ventral mounts accounted for $13 \%$ of observations and all other behaviours accounted for less than $7 \%$ each. Spawning was only observed 4 times, and the behaviours 'circling' ( $\mathrm{n}=5$ ) and 'lateral display' $(\mathrm{n}=2)$ were similarly infrequent. Reproductive behaviour was associated with depth (MANOVA, Pillai's Trace, $\left.F_{10,176}=2.6, \mathrm{p}=0.006\right)$. Chases were more frequent at the tank bottom than in the surface stratum 


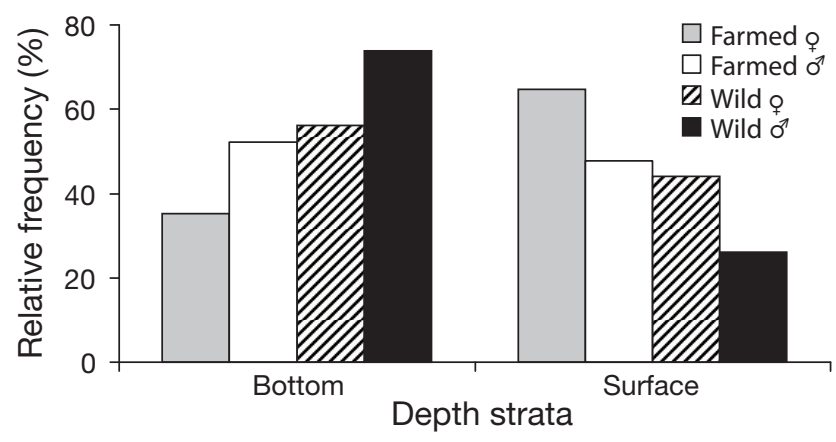

Fig. 2. Gadus morhua. Depth distribution of farmed and wild fish of each sex in the laboratory study ( 7 to 26 March 2006). Bars are the relative frequency of observations (\%) in each category of fish type and sex ( $\mathrm{n}=100$ wild $\sigma^{7}, 322$ wild ,

111 farmed o, 51 farmed o, observations for all 40 fish)

$\left(F_{2,91}=5.3, \mathrm{p}<0.005\right.$, Waller-Duncan post hoc test, $\mathrm{p}<$ $0.05)$, whereas paired swims $\left(F_{2,91}=3.8, \mathrm{p}<0.025\right.$, Waller-Duncan, $\mathrm{p}<0.05)$ and ventral mounts $\left(F_{2,91}=\right.$ $3.2, \mathrm{p}=0.047$, Waller-Duncan, $\mathrm{p}<0.05$ ) were more frequent midwater. Dorsal mounts and approaches were not significantly affected by depth ( $\mathrm{p}$ values from 0.18 to 0.31). All 4 spawning events were at the surface and began with a male ventrally mounting a female in the midwater stratum.

Of behavioural interactions between males where both fish were identified, all 6 interactions between wild males occurred in the bottom stratum, whereas farmed-farmed $(n=6)$ and farmed-wild $(n=6)$ interactions occurred across all 3 depth strata. Farmed males courted farmed $(n=5)$ and wild females $(n=4)$ in the middle and upper strata, whereas wild males courted females of both types across all 3 depth strata $(n=6$ wild $\sigma^{\natural}$-farmed $\circ, 7$ wild $\sigma^{\natural}$ - wild of).

\section{Expt 2. Field study}

\section{Residency}

Following release, 9 farmed (4 o and $5 \sigma^{7}$ ) and 2 wild $\operatorname{cod}\left(1 \circ\right.$ and $\left.1 \sigma^{7}\right)$ departed the area within the first 72 $\mathrm{h}$ and never returned. Others departed immediately but came back, and 1 farmed female lost the transmitter soon after release. In total, 14 farmed fish $(61 \%$ of 23 tracked fish) and 22 wild fish (88\% of 24 tracked fish) were resident at the spawning ground for more than $3 \mathrm{~d}$. Residency times (mean $\pm \mathrm{SE}$ ) for farmed fish were $14.1 \pm 4.6 \mathrm{~d}$ for females and $11.3 \pm 4.1 \mathrm{~d}$ for males Residency for wild fish was $17.8 \pm 3.9 \mathrm{~d}$ for females and $22 \pm 3.6 \mathrm{~d}$ for males. Wild fish had significantly longer residency than farmed fish $\left(F_{1,44}=7.5, \mathrm{p}=0.028\right)$, but neither sex nor a sex-type interaction were significant ( $p$ values from 0.50 to 0.82 ).
Males tended to aggregate in the centre of the spawning ground, whereas females tended to be more dispersed. A circle with radius of $255 \mathrm{~m}$ from the centre of the buoy array encompassed $90 \%$ of positions of $90 \%$ of individual wild males. This area was similar for farmed males $(260 \mathrm{~m})$, but larger for both wild $(375 \mathrm{~m})$ and farmed females (305 m).

\section{Vertical distribution: sex, type and diel effect}

We analysed depth data for 38 fish (11 wild $\sigma^{7} ; 11$ wild o; 9 farmed $0^{\prime} ; 7$ farmed o, Appendix 2). Overall, wild cod had a deeper distribution than farmed cod $(t=-3.49, \mathrm{df}=34, \mathrm{p}=0.001$, Fig. 3a) and males were deeper than females $(t=-5.15$, df $=34, \mathrm{p}<0.001$, Fig. 3a). However, there was a significant interaction

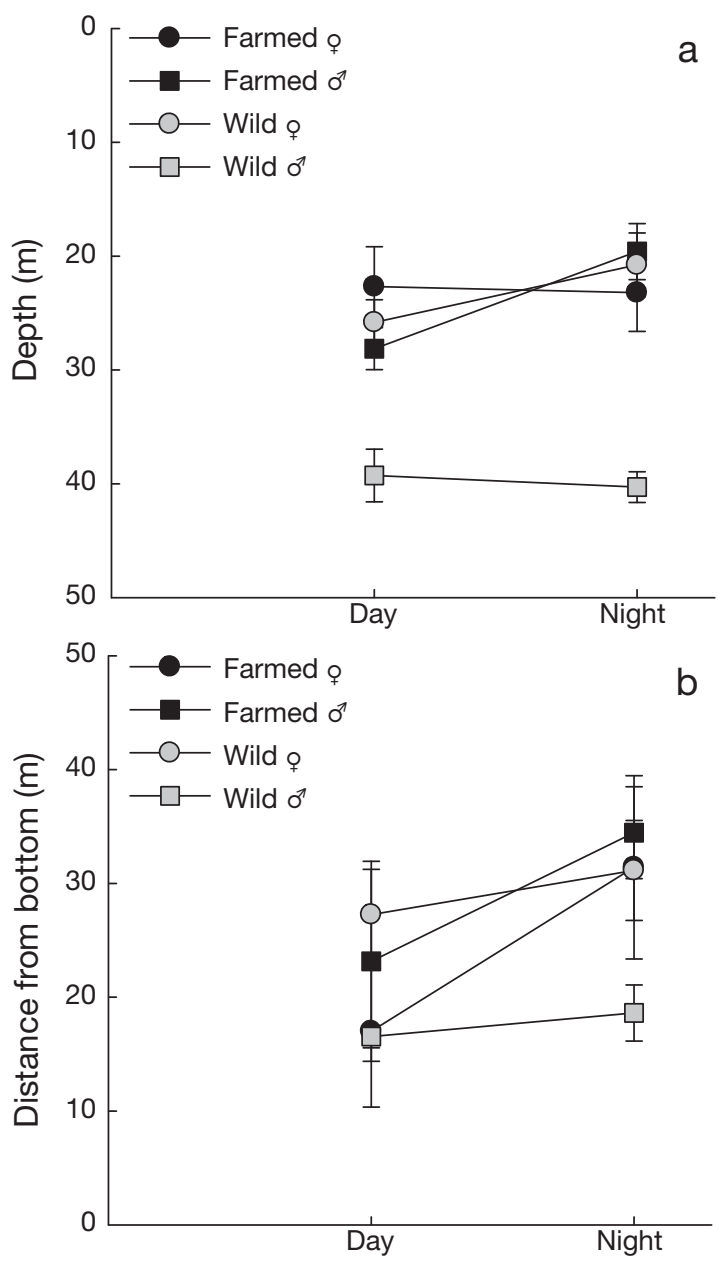

Fig. 3. Gadus morhua. Vertical dynamics of farmed and wild cod on a spawning ground from 20 February to 25 March 2007. (a) Mean depth of farmed and wild cod of both sexes (11 wild $o^{7} ; 11$ wild op; 9 farmed $o^{7} ; 7$ farmed o), and (b) mean distance from the seafloor of farmed and wild cod of both sexes (10 wild $\sigma^{7} ; 10$ wild o; 6 farmed $\sigma^{7} ; 7$ farmed o). Each graph shows the aggregate mean of individuals $\pm \mathrm{SE}$ 
between sex and fish type $(t=3.19$, df $=34, \mathrm{p}=$ 0.003), because wild males were much deeper than wild females, whereas the sex difference was smaller for farmed cod (Fig. 3a). There was also a significant interaction between sex, diel effect and fish type $(t=$ 6.49, df $=377, \mathrm{p}<0.001$, Fig. 3a). Wild males stayed more or less at the same depth during day and night, whereas wild females moved closer to the surface at night. The reverse pattern was found for farmed cod (Fig. 3a); farmed females were at similar depths day and night, and farmed males moved closer to the surface at night. Hence, the mean depths of farmed male cod and wild females were similar during both the day and night.

Generally, the distance from seafloor data supported the overall dataset, although there were fewer data points (34 fish: 10 wild $\sigma^{*} ; 10$ wild o; 6 farmed $\sigma^{7} ; 7$ farmed o, Appendix 2). However, these data were more likely to be for fish near the spawning arena because fish were positioned with greater accuracy close to the centre of the positioning array (Fig. 1), whereas depths were received for all fish within range $(<1 \mathrm{~km})$. There was again an interaction between sex and fish type $(t=-2.59, \mathrm{df}=30, \mathrm{p}=0.015)$, because wild males tended to stay much closer to the seafloor than wild females, whereas the difference between sexes was small for farmed cod (Fig. 3b). Cod were closer to the seafloor during the day than at night ( $t=$ 5.86, df $=30, p<0.001$, Fig. $3 b$ ). There was also a significant interaction between sex, diel effect and fish type $(t=-6.48, \mathrm{df}=275, \mathrm{p}<0.001$, Fig. $3 \mathrm{~b})$, with the strongest diel effect for farmed females (Fig. 3b). Farmed females had a depth distribution that overlapped with wild males during the day but not during the night (Fig. 3b). No other parameters or interactions were significant.

\section{DISCUSSION}

As predicted, farmed fish maintained positions closer to the water surface than their wild counterparts both in the laboratory and field. In the laboratory, reproductive behaviour was strongly affected by depth, and males of both farmed and wild fish tended to be deeper than females. Hence, the depth-related behaviour of farmed cod was at least to some extent similar to that of wild cod, despite the extreme contrast in rearing environments. In the field, a substantial proportion (61\%) of farmed cod remained on the spawning ground for more than $3 \mathrm{~d}$, and vertical distribution patterns of fish were similar to those in the laboratory. However, the scale of these patterns was very different because wild males were close to the seafloor, whereas the other fish types had pelagic depth distributions. Farmed males were thus clearly separated from wild males in the field, whereas the depth distributions of farmed and wild females overlapped. These results suggest that farmed cod, and in particular, farmed females, are likely to hybridise with wild cod on natural spawning grounds.

\section{Why were farmed fish closer to the surface?}

One explanation for the shallow distribution of the farmed fish in our study was that the morphology or physiology of farmed fish differed from wild fish. Farmed cod have larger lipid reserves (Kjesbu 1989), and lipids are around $14 \%$ more buoyant than other somatic tissue (Harden-Jones \& Scholes 1985, Bone et al. 2004), but even if we assume the upper range of lipid content for farmed cod (Shahidi \& Dunajski 1994) they were likely to have been able to attain negative buoyancy. While greater buoyancy may still increase the cost of vertical movements for farmed fish, it did not prevent visits to the bottom of the laboratory tank and to depths of up to $60 \mathrm{~m}$ on the spawning ground. Further, it is unlikely that differences in swimbladder function explained our results, because the depths of farmed and wild cod clearly differed even in the shallow laboratory tank, where the pressure difference was only small (0.14 ATA). However, disentangling the physiological, morphological and behavioural basis for why farmed fish are shallower than wild fish was not the intention of this study and should be the focus of further work. Nevertheless, behavioural choice rather than physiological imperative is not only the most parsimonious explanation, but also the most plausible. Earlier studies have shown that surface feeding and high stocking densities create strong benefits for hatchery fish that adopt shallow positions (Reinhardt 2001, reviewed by Olla et al. 1994). Adult farmed cod are kept in sea pens that are much deeper than hatchery tanks, yet they are still surface fed and limited to a very narrow depth range compared to their wild counterparts.

\section{Vertical dynamics and reproductive behaviour}

Our results suggest that behaviour also drives the differences in vertical dynamics between sexes. Reproductive behaviour in the laboratory was strongly affected by depth, and wild males were considerably deeper than wild females on a natural spawning ground. Male farmed fish also tended to be deeper than farmed females, although this difference was much greater for wild fish. Interpreting these vertical 
dynamics in the context of the reproductive success of farmed cod in the wild and hybridisation with wild cod depends on an understanding of their underlying function.

Spatial separation of male and female cod has been attributed to a lek-like mating system, with batchspawning females attending aggregations of males only when they are ready to spawn (Nordeide \& Folstad 2000, Windle \& Rose 2006). Although not previously demonstrated at the level of individuals and at such a fine spatial scale, numerous studies have observed that the depth distributions of male and female cod differ on spawning grounds (e.g. Morgan \& Trippel 1996, Windle \& Rose 2006). The actual depths of males and females vary between different spawning grounds, but in most studies, males were aggregated near the seafloor, while females were in surrounding waters (e.g. Morgan \& Trippel 1996, Windle \& Rose 2006). The higher rates of agonistic interactions at the bottom of our laboratory tank support the notion that such male aggregations are 'lekking' arenas. Females were courted mainly above the spawning arena in the midwater and surface strata. Spawning was rarely observed as it occurred mainly during darkness (J. Meager unpublished data), but all 4 spawning events involved a slow ascent by the mated pair from the midwater stratum and gamete release near the surface.

Agonistic competition and courtship of females have been linked to reproductive success of cod (Hutchings et al. 1999, Rowe et al. 2008). Hence, the reproductive success of farmed fish in the field is likely to be driven by male-male and female-male distributional overlaps. Wild males were close to the seafloor, whereas farmed males spent much more time in the pelagic (Fig. 3). While this may suggest that farmed males were competitively excluded from the wild spawning arena, it is more likely that farmed fish simply preferred positions closer to the surface, because they maintained shallower depths over the whole spawning ground. All the same, this could indicate that by not attending the spawning arena, the farmed males had reduced spawning success with wild females. It might be argued that the position of farmed males over the spawning arena and the midwater spawning location reflects an alternative spawning strategy, with 'satellite' males rushing in to release milt after a mated pair has spawned (Hutchings et al. 1999). In our laboratory experiment, we were unable to identify such males, and the results of a concurrent study suggest that such a strategy is unsuccessful for farmed males because they performed poorly in sperm competition against wild cod (Skjæraasen et al. 2009).

Farmed males did, however, have a very similar depth distribution to wild females during the day and night (Fig. 3) and may therefore interact with wild females, as was observed in the laboratory. Based on the assumption that wild females avoid the spawning arena in the spawning interval, harassment of unresponsive females in the spawning interval is a potential negative impact of these interactions, although the tendency of farmed males to restrict movements towards pelagic waters in the centre of the spawning ground suggests that such interactions would be spatially limited. Farmed males also had a similar depth distribution to farmed females in the laboratory and field, and reproduce in captivity (e.g. Kjesbu 1989), suggesting that farmed cod may spawn in the wild irrespective of whether wild cod are present.

Farmed females had a similar depth and spatial distribution to wild females. Wild females tended move towards the surface at night, and this was evident only in the distance from seafloor data for farmed females, but in general the vertical dynamics of farmed females strongly resembled that of wild females. This implies that reproductive behaviour is also similar, a suggestion supported by observations of courtship interactions between farmed female and wild male cod in the laboratory, and of individual farmed female and wild cod in close contact in the field (J. Meager unpubl. data). In our study, farmed females also were on average a similar distance from the seafloor to wild males during the day (Fig. 3b). The distance from seafloor data were determined for positions closer to the main spawning arena and thus more likely to involve reproductive behaviour. Together, these results suggest that farmed females represent a potential vector for hybridisation and genetic introgression into wild gene pools.

\section{Applications to management}

Escaped farmed cod, and in particular, farmed females are likely to hybridise with wild cod. Farmed females had similar depth-related reproductive behaviour to wild females and were courted by wild males in the laboratory. In contrast, the depth distribution of farmed males in the field clearly separated them from the spawning arena, suggesting that their reproductive success was reduced. The overlap in depth distributions of farmed fish and wild females suggests that targeting recaptures of escaped farmed cod during the spawning season would be difficult, but earlier experiments suggest that this may be possible at other times and for several years after release (Svåsand \& Kristiansen 1990, Nøstvik \& Pedersen 1999).

Further research into the reproductive success of farmed cod in the field and on other spawning grounds is clearly warranted if we are to protect the genetic integrity of local cod populations. Fitness depression in 
wild populations has been the cost of introgression of farmed salmonid genes into wild gene pools (McGinnity et al. 2003, review by Naylor et al. 2005). In comparison, domestication of cod is in its infancy, but recent work indicates that the genetic effects of domestication on the fitness of fish in the wild are extremely rapid (Araki et al. 2007), and brood-stock domestication selection in cod is already underway in Canada, Iceland and Norway. We are currently examining the reproductive success of farmed and wild cod in the laboratory. Nevertheless, until further information on the reproductive behaviour and success of escapee cod is available, the precautionary principle dictates that efforts should be directed towards operational measures and technology to avoid escapes.

Acknowledgements. Financial support was provided by the Research Council of Norway, through the INTERACTIONS (NRC no. 172649) and VERTICAL projects (NRC no. 178975). Experimental procedures complied with the Norwegian Council for Animal Research. We thank IMR staff at Austevoll and in the Fish Capture Division, I. Mayer, D. Webber, volunteers who helped in the field, and K. Heimark and the other local fishermen at Osen. Our appreciation also extends to I. Svellingen, J. Kolding, A. Totland and A. Staby for assistance with the echosounding.

\section{LITERATURE CITED}

Aglen A, Engås A, Huse I, Michalsen K, Stensholt BK (1999) How vertical fish distribution may affect survey results. ICES J Mar Sci 56:345-360

Ames EP (2004) Atlantic cod stock structure in the Gulf of Maine. Fisheries 29:10-28

Araki H, Cooper B, Blouin MS (2007) Genetic effects of captive breeding cause a rapid, cumulative fitness decline in the wild. Science 318:100-103

Baird TA, Olla BL (1991) Social and reproductive behaviour of a captive group of walleye pollock, Theragra chalcogramma. Environ Biol Fishes 30:295-301

Bekkevold D, Hansen MM, Nielsen EE (2006) Genetic impact of gadoid culture on wild fish populations: predictions, lessons from salmonids, and possibilities for minimizing adverse effects: Gadoid mariculture: development and future challenges. ICES J Mar Sci 63:198-208

Bone M, Marshall NB, Blaxter JHS (2004) Biology of fishes. Bios Scientific Publishers, Abington

Bradbury IR, Snelgrove PVR, Fraser S (2000) Transport and development of eggs and larvae of Atlantic cod, Gadus morhua, in relation to spawning time and location in coastal Newfoundland. Can J Fish Aquat Sci 57: 1761-1772

Brawn VM (1961) Reproductive behaviour of the cod (Gadus callarias L.). Behaviour 18:177-197

- Clark CW, Levy DA (1988) Diel vertical migrations by juvenile sockeye salmon and the antipredation window. Am Nat 131:271-290

> Dickson TA, MacCrimmon HR (1982) Influence of hatchery experience on growth and behaviour of juvenile Atlantic salmon (Salmo salar) within allopatric and sympatric stream populations. Can J Fish Aquat Sci 39:1453-1458
Harden Jones FR, Scholes P (1985) Gas secretion and reabsorption in the swimbladder of the cod Gadus morhua. J Comp Physiol B 155:319-331

> Hutchings JA, Bishop TD, McGregor-Shaw CR (1999) Spawning behaviour of Atlantic cod, Gadus morhua: evidence of mate competition and mate choice in a broadcast spawner. Can J Fish Aquat Sci 56:97-104

Karlsen O, Holm JC (1994) Ultrasonography, a noninvasive method for sex determination in cod (Gadus morhua). J Fish Biol 44:965-971

- Kjesbu OS (1989) The spawning activity of cod, Gadus morhua L. J Fish Biol 34:195-206

Kjesbu OS, Kryvi H, Sundby S, Solemdal P (1992) Buoyancy variations in eggs of Atlantic cod (Gadus morhua L) in relation to chorion thickness and egg size: theory and observations. J Fish Biol 41:581-599

Lawson GL, Rose GA (2000) Small-scale spatial and temporal patterns in spawning of Atlantic cod (Gadus morhua) in coastal Newfoundland waters. Can J Fish Aquat Sci 57: 1011-1024

Lobel P (1992) Sounds produced by spawning fishes. Environ Biol Fishes 33:351-358

> McGinnity P, Prodohl P, Ferguson K, Hynes R and others (2003) Fitness reduction and potential extinction of wild populations of Atlantic salmon, Salmo salar, as a result of interactions with escaped farm salmon. Proc R Soc Lond B Biol Sci 270:2443-2450

Moe H, Dempster T, Sunde LM, Winther U, Fredheim A (2007) Technological solutions and operational measures to prevent escapes of Atlantic cod (Gadus morhua) from sea cages. Aquacult Res 38:91-99

> Morgan MJ, Trippel EA (1996) Skewed sex ratios in spawning shoals of Atlantic cod (Gadus morhua). ICES J Mar Sci 53: $820-826$

Naylor R, Hindar K, Fleming IA, Goldburg R and others (2005) Fugitive salmon: assessing the risks of escaped fish from net-pen aquaculture. Bioscience 55:427-437

> Neilson JD, Perry RI (1990) Diel vertical migrations of marine fishes - an obligate or facultative process? Adv Mar Biol 26:115-168

Nordeide J, Folstad I (2000) Is cod lekking or a promiscuous group spawner? Fish Fish 1:90-93

Nøstvik F, Pedersen T (1999) Movement patterns and growth of wild cod (Gadus morhua L.) and hatcheryreared cod released as 1-group. In: Howell BR, Moksness E, Svåsand T (eds) Stock enhancement sea ranching. Fishing news books, Blackwell Science, Oxford, p 315-333

Olla BL, Davis MW, Ryer CH (1994) Behavioural deficits in hatchery-reared fish: potential effects on survival following release. Aquacult Fish Manag 25:19-34

Pankhurst NW, Fitzgibbon QP (2006) Characteristics of spawning behaviour in cultured greenback flounder Rhombosolea tapirina. Aquaculture 253:279-289

R Development Core Team (2008) R: a language and environment for statistical computing. R Foundation for Statistical Computing, Vienna

Reinhardt UG (2001) Selection for surface feeding in farmed and sea-ranched masu salmon juveniles. Trans Am Fish Soc 130:155-158

Rollefsen G (1933) The otoliths of the cod. Fiskeridir Skr (Havunders) 4:1-14

> Rooker JR, Bremer JRA, Block BA, Dewar H and others (2007) Life history and stock structure of Atlantic bluefin tuna (Thunnus thynnus). Rev Fish Sci 15:265-310

> Rose GA (1993) Cod spawning on a migration highway in the north-west Atlantic. Nature 366:458-461 
Rowe S, Hutchings JA, Skjæraasen JE, Bezanson L (2008) Morphological and behavioural correlates of reproductive success in Atlantic cod Gadus morhua. Mar Ecol Prog Ser 354:257-265

Shahidi F, Dunajski E (1994) Lipid fatty acids, growth and compositional characteristics of farmed cod (Gadus morhua). J Food Lipids 1:265-271

Skjæraasen JE, Mayer I, Meager JJ, Rudolfsen G, Karlsen Ø, Haugland T, Kleven O (2009) Sperm characteristics and competitive ability in farmed and wild cod. Mar Ecol Prog Ser 375:219-228

Svåsand T, Kristiansen TS (1990) Enhancement studies of coastal cod in western Norway. Part II. Migration of reared coastal cod. ICES J Mar Sci 47:13-22

Svåsand T, Jørstad KE, Kristiansen TS (1990) Enhancement studies of coastal cod in western Norway. Part I. Recruitment of wild and reared cod to a local spawning stock. ICES J Mar Sci 47:5-12
Uglem I, Bjorn PA, Dale T, Kerwath S and others (2008) Movements and spatiotemporal distribution of escaped farmed and local wild Atlantic cod (Gadus morhua L.). Aquacult Res 39:158-170

Vincent RE (1960) Some influences of domestication upon three stocks of brook trout (Salvelinus fontinalis Mitchill). Trans Am Fish Soc 89:35-52

Windle M, Rose G (2006) Do cod form spawning leks? Evidence from a Newfoundland spawning ground. Mar Biol 150:671-680

Wroblewski JS, Smedbol RK, Taggart CT, Goddard SV (1996) Movements of farmed and wild Atlantic cod (Gadus morhua) released in Trinity Bay, Newfoundland. Mar Biol 124:619-627

Zamora L, Moreno-Amich R (2002) Quantifying the activity and movement of perch in a temperate lake by integrating acoustic telemetry and a geographic information system. Hydrobiologia 483:209-218

Appendix 1. Gadus morhua. Descriptions of reproductive behaviours observed in our spawning groups, based on earlier experiments and published accounts (Brawn 1961, Hutchings et al. 1999, Rowe et al. 2008). Agonistic interactions also occur outside of the spawning season (Brawn 1961), but as they are linked to reproductive success in cod (Rowe et al. 2008), we refer to them here as 'reproductive behaviours'. Behavioural acts from 3 to 8 were coded as both the initiator (e.g. 'Approach') and receiver (e.g. 'Approached'), but only the initiator is considered here

\begin{tabular}{|lll|}
\hline \multicolumn{2}{|c|}{ Behaviour } & \\
\hline 1 & Chase & Direct orientation towards another fish followed by rapid pursuit \\
2 & Flee & Burst swimming away from another fish \\
3 & Approach & Direct orientation towards another fish followed by slowly swimming towards that fish \\
4 & Circling & Swimming around a fish that is motionless on the bottom \\
5 & Lateral display & Approaching another fish and freezing. Pectoral and pelvic fins are flexed for a minimum of $2 \mathrm{~s}$ \\
6 & Paired swim & Slowly following another fish and making at least 2 corresponding alterations of direction \\
7 & Dorsal mount & Pressing ventral surface against dorsal side of another fish \\
8 & Ventral mount & Sliding down along the side of another fish, ending up underneath \\
9 & Spawning & Release of sperm by 1 or several males in the immediate vicinity of a female that has released eggs \\
& &
\end{tabular}


Appendix 2. Gadus morhua. Details of sample sizes (n) in the field study (excluding the first $24 \mathrm{~h}$ ). Tag no. refers to the serial number of continuously transmitting (Cont.) and individually coded tags (Coded)

\begin{tabular}{|c|c|c|c|c|}
\hline Sex and type & Tag no. & Tag system & $\begin{array}{l}\text { Depth } \\
\text { (n) }\end{array}$ & $\begin{array}{c}\text { Distance from } \\
\text { seafloor (n) }\end{array}$ \\
\hline Farmed o & 183 & Coded & 3654 & 1106 \\
\hline Farmed 우 & 204 & Coded & 65 & 21 \\
\hline Farmed 우 & 205 & Coded & 31 & 5 \\
\hline Farmed o & 208 & Coded & 2510 & 112 \\
\hline Farmed o & 215 & Coded & 144 & 42 \\
\hline Farmed o & 9656 & Cont. & 3956 & 801 \\
\hline Farmed o & 9657 & Cont. & 4395 & 40 \\
\hline Farmed $0^{7}$ & 178 & Coded & 30 & 12 \\
\hline Farmed $0^{7}$ & 179 & Coded & 45 & 13 \\
\hline Farmed $0^{7}$ & 182 & Coded & 5255 & 2457 \\
\hline Farmed $o^{7}$ & 201 & Coded & 10 & - \\
\hline Farmed $o^{7}$ & 206 & Coded & 1087 & 364 \\
\hline Farmed $0^{7}$ & 209 & Coded & 12 & 1 \\
\hline Farmed $0^{x}$ & 217 & Coded & 5 & 1 \\
\hline Farmed $o^{x}$ & 9649 & Cont. & 3373 & 32 \\
\hline Farmed $0^{7}$ & 9654 & Cont. & 3179 & 2 \\
\hline Wild o & 181 & Coded & 3 & - \\
\hline Wild o & 186 & Coded & 905 & 62 \\
\hline Wild o & 187 & Coded & 1537 & 196 \\
\hline Wild o & 189 & Coded & 3060 & 640 \\
\hline Wild o & 192 & Coded & 1389 & 202 \\
\hline Wild o & 193 & Coded & 193 & 25 \\
\hline Wild o & 195 & Coded & 103 & 21 \\
\hline Wild o & 210 & Coded & 214 & 5 \\
\hline Wild o & 214 & Coded & 2702 & 599 \\
\hline Wild o & 9651 & Cont. & 3889 & 2743 \\
\hline Wild o & 9652 & Cont. & 2589 & 405 \\
\hline Wild $0^{7}$ & 190 & Coded & 3613 & 850 \\
\hline Wild o' & 191 & Coded & 2528 & 485 \\
\hline Wild o' & 194 & Coded & 1691 & 164 \\
\hline Wild o' & 197 & Coded & 1825 & 458 \\
\hline Wild $0^{7}$ & 198 & Coded & 1195 & 316 \\
\hline Wild $0^{7}$ & 199 & Coded & 3563 & 533 \\
\hline Wild $0^{7}$ & 200 & Coded & 89 & 1 \\
\hline Wild o $0^{7}$ & 211 & Coded & 162 & 34 \\
\hline Wild $0^{7}$ & 213 & Coded & 3114 & 534 \\
\hline Wild $\sigma^{1}$ & 9658 & Cont. & 4235 & 2488 \\
\hline Wild o & 9659 & Cont. & 4327 & 2569 \\
\hline
\end{tabular}

Editorial responsibility: Jana Davis, Annapolis, Maryland, USA
Submitted: August 5, 2008; Accepted: June 10, 2009

Proofs received from author(s): August 16, 2009 